Meta

Journal des traducteurs

Translators' Journal

\title{
Investigating Translation Competence: Conceptual and Methodological Issues
}

\section{PACTE group}

Volume 50, numéro 2, avril 2005

Processus et cheminements en traduction et interprétation Processes and Pathways in Translation and Interpretation

URI : https://id.erudit.org/iderudit/011004ar

DOI : https://doi.org/10.7202/011004ar

Aller au sommaire du numéro

Éditeur(s)

Les Presses de l'Université de Montréal

ISSN

0026-0452 (imprimé)

1492-1421 (numérique)

Découvrir la revue

Citer cet article

PACTE group (2005). Investigating Translation Competence: Conceptual and Methodological Issues. Meta, 50(2), 609-619. https://doi.org/10.7202/011004ar
Résumé de l'article

Le groupe PACTE conduit une recherche empirique-expérimentale sur la compétence de traduction et son processus d'acquisition en traduction écrite. Cet article explique comment est conçue la recherche sur la compétence de traduction et rend compte des résultats d'une épreuve pilote dont l'objectif était d'évaluer les modalités de la recherche et l'efficacité des instruments qui seraient utilisés pour l'expérimentation définitive. Ces premiers résultats concernant le mode de fonctionnement de la prise de décisions au cours du processus de traduction ainsi que l'interrelation entre l'utilisation de l'aide interne et de l'aide externe montrent, d'une part, que ce fonctionnement est différent entre traducteurs professionnels et autres professionnels enseignant des langues, et, d'autre part, que les instruments à disposition sont efficaces.
Ce document est protégé par la loi sur le droit d'auteur. L'utilisation des services d'Érudit (y compris la reproduction) est assujettie à sa politique d'utilisation que vous pouvez consulter en ligne.

https://apropos.erudit.org/fr/usagers/politique-dutilisation/ 


\title{
Investigating Translation Competence: Conceptual and Methodological Issues
}

\author{
PACTE GROUP \\ (A. Beeby, M. Fernández, O. Fox, I. Kozlova, W. Neunzig, M. Presas, \\ P. Rodríguez, L. Romero. Principal investigator: A. Hurtado Albir)
}

\begin{abstract}
RÉSUMÉ
Le groupe PACTE conduit une recherche empirique-expérimentale sur la compétence de traduction et son processus d'acquisition en traduction écrite. Cet article explique comment est conçue la recherche sur la compétence de traduction et rend compte des résultats d'une épreuve pilote dont l'objectif était d'évaluer les modalités de la recherche et l'efficacité des instruments qui seraient utilisés pour l'expérimentation définitive. Ces premiers résultats concernant le mode de fonctionnement de la prise de décisions au cours du processus de traduction ainsi que l'interrelation entre l'utilisation de l'aide interne et de l'aide externe montrent, d'une part, que ce fonctionnement est différent entre traducteurs professionnels et autres professionnels enseignant des langues, et, d'autre part, que les instruments à disposition sont efficaces.
\end{abstract}

\begin{abstract}
The PACTE group uses empirical-experimental research methods to investigate translation competence and how it is acquired. This article presents the design of our Translation Competence research project and the first results of a pilot test carried out to evaluate our research design and the instruments that will be used in the experiment. The first results of the pilot test are related to decision-taking in the translation process and the interrelation between the use of internal and external support. The results point to differences in the processes followed by professional translators and other language professionals. Furthermore, the pilot test has proved the reliability of our instruments.
\end{abstract}

\section{MOTS CLÉS/KEY WORDS}

empirical-experimental research, translation competence, decision-taking, internal support, external support

\section{Introduction: the PACTE Group Research project}

Our research aims at a better understanding about how translation competence is acquired. The project has two main stages: (1) a study of translation competence (TC) (2) a study of the acquisition of translation competence. This first stage, in which we are currently working, is essential, given the lack of empirical studies on how TC functions. We work with 6 language combinations: German, French and English (as B languages) - Spanish and Catalan (as A languages). ${ }^{1}$

This is an empirical-experimental research project that studies both the translation process and the translation product. Thus, different methods are used to collect data about the process (experimental studies) and the product (corpus methodology) and the results are triangulated. However, given the lack of empirically tested translation competence models and validated data collecting instruments, we had to begin with exploratory and pilot tests before embarking on the final experiment. In 
2000 an observational exploratory test was carried out with 5 professional translators (PACTE, 2002); in 2004 a pilot test was carried out with 3 professional translators and 3 foreign-language teachers, the results of which are now being analysed.

\section{Translation Competence}

The main aim of this first stage of our research is to identify the distinguishing features of translation competence. However, there are two collateral objectives: (1) to validate our holistic TC model; (2) to validate the TC measuring instruments.

Our TC model was first presented in 1998 and later on (PACTE 1998a, 1998b, $2000,2001)$, and it was recently remodelled in the light of the results of the 2000 exploratory test (PACTE 2003). In this model, TC is considered to be the underlying knowledge system needed to translate and has four distinctive characteristics: (1) it is expert knowledge and not possessed by all bilinguals; (2) it is basically procedural knowledge (and not declarative); (3) it is made up of various interrelated sub-competencies; (4) the strategic component is very important, as it is in all procedural knowledge. The TC model proposed is made up of 5 sub-competencies and psychophysiological components (PACTE 2003).

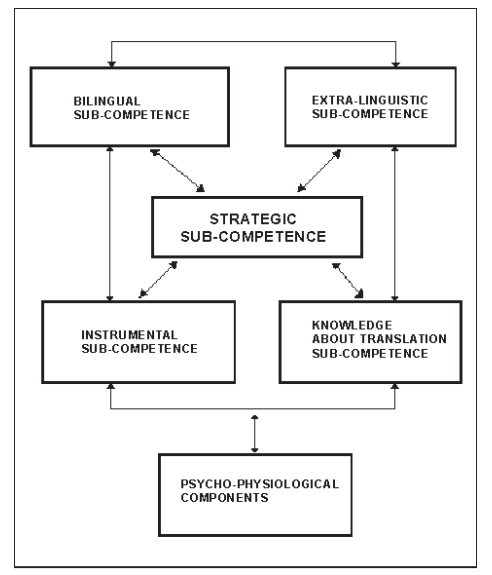

The bilingual sub-competence is made up of pragmatic, socio-linguistic, textual and lexical-grammatical knowledge in each language. The extra-linguistic sub-competence is made up of encyclopaedic, thematic and bicultural knowledge. The translation knowledge sub-competence is knowledge of the principles that guide translation (processes, methods and procedures, etc.) and the profession (types of translation briefs, users, etc.). The instrumental sub-competence is made up of knowledge related to the use of documentation sources and information technologies applied to translation. The strategic sub-competence is the most important, as it is responsible for solving problems and the efficiency of the process. It intervenes by planning the process in relation to the translation project, evaluating the process and partial results obtained, activating the different sub-competencies and compensating for deficiencies, identifying translation problems and applying procedures to solve them. The psycho-physiological components are cognitive and behavioural (memory, attention span, perseverance, critical mind, etc.) and psychomotor mechanisms. 
Given that any bilingual has knowledge of two languages and may have extralinguistic knowledge, we consider that the sub-competencies specific to TC are the strategic, the instrumental and knowledge about translation. Therefore, our research is focused on these three sub-competencies. Empirical and operative hypotheses have been formulated using this model, beginning with the basic hypothesis that the translator's degree of expertise influences the translation process and product.

\section{Research design}

\subsection{Universe and sample}

The universe from which our sample taken: is professionals working with foreign languages and two groups of subjects have been selected: expert translators and teachers of foreign languages. Teachers of foreign languages with at least six years of experience were chosen because they share some of the characteristics of expert translators; according to our model, they possess the bilingual and extra-linguistic sub-competences but not the other three. We define expert translators as translators with at least 6 years of experience in a variety of fields for whom translation is their main professional activity and provides at least $70 \%$ of their income.

\subsection{Data collecting materials}

Different types of materials have been used to collect data about the translation process and product so that the results can be triangulated.

1. Texts and translations. Electronic corpus of source texts (for direct and inverse translation) and translations carried out in the experiment. The source texts have been selected using the following criteria: (1) texts of the same genre in the same field for all the languages studied; (2) texts with a rich variety of problems; (3) short texts (175 to 300 words); (4) text genres translated by professional translators in Spain.

2. Translation protocols (Neunzig 2000): PROXY recordings. PROXY is a programme (compatible with Windows) designed for the remote control of computers and users connected to a network. By using PROXY it is possible to view and record the subjects' actions on the computer in real time and store these recordings for later study and data collection.

3. Direct observation. Direct observation is also used to collect data about the translators' behaviour that cannot be recorded by PROXY.

4. Questionnaires. Different types of questionnaires are used: (1) an initial questionnaire to select subjects, (2) a questionnaire for subjects to identify the problems encountered in the translation process, (3) a questionnaire to measure the subjects' knowledge about translation

5. Retrospective interviews. Data are also collected in retrospective interviews with the subjects while viewing the PROXY recording.

\subsection{Experimental tasks}

The tasks carried out by the subjects are: (1) Translation into their A language (direct translation); (2) Filling in a questionnaire about the problems encountered in the translation; (3) Translation into their B language (inverse translation); (4) Filling in a questionnaire about the problems encountered in the translation; (5) Filling in a 
questionnaire about translation knowledge; (6) Participating in a retrospective interview while viewing their PROXY recording. The translation process is recorded through PROXY and direct observation.

\subsection{Research variables}

In this study there is one independent variable and five dependent variables. The independent variable is translation expertise defined as years working as a translator when this is the main professional activity. The two experimental groups are constituted following this definition: Group 1: expert translators (more than 6 years of experience); Group 2: language teachers (zero years of translation experience). The dependent variables are: the translation project, the identification of translation problems, decision taking, translation knowledge and efficiency of the process. The following aspects have been defined for each variable: objective, conceptual definition, operative definition, operative hypotheses, indicators, materials and instruments. For reasons of space, in the following table we will only present the conceptual definition, indicators, materials and instruments.

\begin{tabular}{|c|c|}
\hline \multicolumn{2}{|c|}{$\begin{array}{l}\text { TRANSLATION PROJECT } \\
\text { This is related to the strategic sub-competence }\end{array}$} \\
\hline $\begin{array}{l}\text { CONCEPTUAL } \\
\text { DEFINITION }\end{array}$ & $\begin{array}{l}\text { Mental representation or expectations of what the translation of a given } \\
\text { text (for a given translation brief) should be like. }\end{array}$ \\
\hline INDICATORS & Degree of elaboration and coherence of the translation project \\
\hline INSTRUMENTS & Problems questionnaire and retrospective interview \\
\hline MEASUREMENT & $\begin{array}{l}\text { Elements taken into account by the subject in relation to the translation } \\
\text { project }\end{array}$ \\
\hline \multicolumn{2}{|c|}{$\begin{array}{l}\text { IDENTIFICATION OF TRANSLATION PROBLEMS } \\
\text { This is related to the translation knowledge sub-competence }\end{array}$} \\
\hline $\begin{array}{l}\text { CONCEPTUAL } \\
\text { DEFINITION }\end{array}$ & Difficulties identified by the subjects when carrying out a translation task \\
\hline INDICATORS & Types of problems identified \\
\hline INSTRUMENTS & Problems questionnaire \\
\hline MEASUREMENT & Number, type and variety of problems identified \\
\hline \multicolumn{2}{|c|}{$\begin{array}{l}\text { DECISION TAKING } \\
\text { This is the most complex variable. It is related to the strategic and instrumental } \\
\text { sub-competencies and provides data about the subjects' procedural behaviour }\end{array}$} \\
\hline $\begin{array}{l}\text { CONCEPTUAL } \\
\text { DEFINITION }\end{array}$ & $\begin{array}{l}\text { Process in which the TC sub-competencies are activated when a } \\
\text { translation task is being carried out. Two categories are used: internal } \\
\text { support and external support }{ }^{2} \text {. Internal support: use of automatic and } \\
\text { non-automatic cognitive resources } \\
\text { External support: use of any kind of documentation source. }\end{array}$ \\
\hline INDICATORS & Types and sequences of actions; acceptability of results \\
\hline INSTRUMENTS & $\begin{array}{l}\text { Translations, direct observation chart, PROXY recordings, retrospective } \\
\text { interviews, chart of action categories and chart of consultation categories. } \\
\text { Selection and characterization of the "rich points" in the ST and criteria } \\
\text { for the acceptability of results }\end{array}$ \\
\hline MEASUREMENT & $\begin{array}{l}\text { Sequences of actions leading to results that are acceptable, partially } \\
\text { acceptable and unacceptable }\end{array}$ \\
\hline
\end{tabular}




\begin{tabular}{|l|l|}
\hline \multicolumn{2}{|l|}{$\begin{array}{l}\text { TRANSLATION KNOWLEDGE } \\
\text { This is related to the translation knowledge sub-competence }\end{array}$} \\
\hline $\begin{array}{l}\text { CONCEPTUAL } \\
\text { DEFINITION }\end{array}$ & $\begin{array}{l}\text { The subject's underlying beliefs about the guiding principles of translation } \\
\text { and aspects of the translation profession }\end{array}$ \\
\hline INDICATORS & $\begin{array}{l}\text { Concepts about: translation and translation competence, translation units, } \\
\text { types of problems, stages in the translation process, methods, procedures, } \\
\text { the function of the translation brief and the TT reader }\end{array}$ \\
\hline INSTRUMENTS & Questionnaire of translation knowledge \\
\hline MEASUREMENT & Subjective concept of the underlying principles of translation \\
\hline $\begin{array}{l}\text { EFFICIENCY OF PROCESS } \\
\text { This is related to the strategic sub-competence }\end{array}$ \\
\hline $\begin{array}{l}\text { CONCEPTUAL } \\
\text { DEFINITION }\end{array}$ & $\begin{array}{l}\text { Optimum relationship between the time invested to solve a translation } \\
\text { task and the acceptability of the solution }\end{array}$ \\
\hline INDICATORS & $\begin{array}{l}\text { Total time; time dedicated to each stage (orientation, development, } \\
\text { revision) }{ }^{3} \text {; acceptability of the results }\end{array}$ \\
\hline INSTRUMENTS & $\begin{array}{l}\text { Translations, direct observation chart, PROXY recordings. Criteria for the } \\
\text { acceptability of the results. }\end{array}$ \\
\hline MEASUREMENT & $\begin{array}{l}\text { Total time and time dedicated to each stage in relation to the acceptable } \\
\text { and partially acceptable results obtained }\end{array}$ \\
\hline
\end{tabular}

\subsection{Instruments}

The main instruments designed to collect data are described briefly here and some are illustrated in the Appendix.

1. Initial questionnaire. Two questionnaires are used, one for each group of subjects, to select those who fulfil the established requirements. They collect data about age, A and $\mathrm{B}$ languages, academic training, translation experience, etc.

2. Categories of actions. In order to follow the decision-taking process adopted by the subjects to solve translation problems, we needed to label the "actions" carried out while they were translating. These actions reflect decisions taken by the subjects and are observable (although they may be the result of other procedures that cannot be observed). Sixteen categories of actions have been identified from the results of the 2000 exploratory test (PACTE 2002): First reading of the ST, Underlining, Provisional solution, Revision, etc. A selection was made of the five categories that were considered to be most relevant to TC:

\section{Reading the source text Pause (+ than 5 seconds) Provisional Solution}

Definitive Solution

Consultation

3. Direct observation chart. This chart is used to collect data on the "external" behaviour of the subjects in each stage of the process (orientation, development and revision) that cannot be recorded by PROXY (See Appendix 1).

4. Problems questionnaire. The subjects fill in this questionnaire after translating each text. They are asked to select 5 elements in the text that are problems for them and indicate the degree of difficulty of the text (See Appendix 2). 
5. Translation knowledge questionnaire. This questionnaire of 36 questions has been designed around the 7 indicators of the translation knowledge variable (translation and translation competence, translation units, etc.). For each indicator, 4 or 5 questions have been formulated based on two paradigms of ways of thinking about translation: one is labelled "dynamic" (textual, communicative, functionalist concepts) and the other "static" (linguistic and literal concepts). Thus, for example, the questions related to the "translation unit" are:

1. (D) The whole text has to be taken into account in order to translate.

2. (D) The ST segment that is translated has no specific length (word, phrase, paragraph). It varies in each case.

3. (S) The best way to translate a text is phrase by phrase.

4. (S) The best way to translate is word for word, unless there are set expressions ormetaphors.

(See Appendix 3)

6. Selection and characterization of "rich points" in the source text. In order to collect data on the decision-taking variable, we decided to concentrate on a few selected elements in the source text. The three essential characteristics of these elements, that we have denominated as "rich points," are: (1) that they should provide variety in the types of translation problems studied, (2) that they do not lead to immediate and acceptable solutions and (3) that they should be homogeneous in all the languages (so comparisons can be made). The inverse translation source text is included in Section 3.2. with the selected elements marked in bold. Each element selected is analysed in terms of the type of problem, its relevant characteristics and the acceptable and partially acceptable characteristics.

7. Criteria used to evaluate the acceptability of results. Criteria of acceptability are needed to study those variables related to the results obtained by the subjects, i.e., decision-taking and efficiency of the process. Criteria have been designed to distinguish between acceptable, partially acceptable and unacceptable solutions:

ACCEPTABLE SOLUTION: Congruence between the ST and the TT. The solution activates all the relevant connotations of the ST in the translation context.

PARTIALLY ACCEPTABLE SOLUTION: Some congruence between the ST and the TT and total congruence within the TT. The solution activates some of the relevant connotations of the ST in the translation context and the TT is congruent in the translation context.

UNACCEPTABLE SOLUTION: No congruence between the ST and the TT or within the TT. Either, the solution does not activate any of the relevant connotations of the ST, or, it activates connotations that are incongruent in the translation context.

8. Chart of consultation categories. In order to describe the subjects' actions, documentation consultations have been classified according to three categories: the type of search carried out, the medium of the information source and the languages used (See Appendix 4). 


\section{First results of the pilot test: use of internal and external support in talking decisions}

We are now analysing the data from the pilot test with 3 expert translators and 3 language teachers. From all the data obtained to date, the information related to the "decision-taking" variable seems to be particularly interesting.

\subsection{Identification of sequences of actions}

The analysis of the subjects' action during the translation process has revealed the existence of a variety of different sequences of actions. These have been classified into five categories according to the degree of cognitive implication required, i.e., in the use of internal and external support. The two extremes are: the use of simple internal support, when a Definitive Solution is reached without any consultation, and the use of simple external support, when the support used to reach a Definitive Solution is a bilingual dictionary. "Complex consultations" have been identified: when there is a chain of consultations or a complex search (for example using an Internet searcher in a contextualized way). The five categories are:

1. Simple internal support (IS). The definitive solution is reached by using internal support alone, without external consultation. Two typical sequences are: (a) Definitive Solution; (b) Pause - Definitive Solution

2. Internal support dominant combined with external support (ISD). Complex documentation searches are made but they do not lead to a definitive solution. The Definitive Solution is the result of internal support. For example: Complex Consultation - Provisional Solution - Pause - Definitive Solution

3. Balanced interaction between internal and external support (IS-ES). Both internal and external support is used and the definitive solution is the result of interaction between the two. Three subcategories have been identified:

a. Consultation (of any kind) is used to confirm a decision. For example: Pause Definitive Solution - Consultation

b. Consultation (bilingual or monolingual dictionary) is used but the dictionary solution is not accepted. For example: BL/ML Consultation - Pause - Provisional Solution - Definitive Solution

c. Internal support is combined with consultation (bilingual or monolingual dictionary) and the solution is accepted. For example: Pause - BL/ML Consultation Definitive Solution

4. External support dominant combined with internal support (ESD). Complex consultations are the basis for a definitive solution. The Definitive Solution is the result of external support. Two examples: (a) Provisional Solution - Pause - BL Consultation - ML Consultation - Definitive Solution; (b) Contextualized Internet searcher - Definitive Solution

5. Simple External Support (ES). A bilingual dictionary is consulted and the solution is accepted. Therefore, the definitive solution is the result of external support. A typical sequence is: BL Consultation - Definitive Solution 
The following graph shows the degree of cognitive implication required for the five categories of sequences:

\begin{tabular}{|c|c|c|c|}
\hline \multicolumn{4}{|c|}{$\begin{array}{l}\text { COGNITIVE IMPLICATION } \\
\text { Internal support - External support }\end{array}$} \\
\hline & $\begin{array}{c}\text { Internal } \\
\text { Support Dominant }\end{array}$ & $\begin{array}{c}\text { External } \\
\text { Support Dominant }\end{array}$ & \\
\hline Simple & & & Simple \\
\hline Internal & & & External \\
\hline & & & port \\
\hline
\end{tabular}

\subsection{Process and product data from the inverse translation task}

By using the above categories, we have been able to triangulate process and product data from the inverse translations of the following text. (The "rich points" selected have been marked in bold).

TRANSLATION BRIEF: The tourism office of the Garraf region in Catalonia has created a web site for tourists in Spanish and Catalan. They also want to offer translations in other languages and you have been asked to provide the English/French/German version.

La Plana Novella es una antigua heredad adquirida por el Indiano Pere Domenech i Grau en 1885 que se encuentra en una pequeña planicie en el centro del Parc Natural del Garraf y pertenece al municipio de Olivella. La Finca fue declarada colonia agrícola 10 años más tarde por el gobierno alfonsino, pero de aquella época perdura una leyenda de desenfreno y dilapidación que hizo desaparecer la fortuna del americano. El estilo arquitectónico del Palacete es ecléctico, es decir que mezcla diferentes estilos. La geografía comarcal de Cataluña lo califica de "Castillo de Bambalinas" como si fuese un decorado de teatro. Sin ningún tipo de duda la construcción estilísticamente más original del Palau Novella es el lavadero gaudiniano, pero una de las piezas más características y llamativas del Palau es la comuna, conocida como "la trona."

The sequences of actions used by the subjects to translate the "rich points" have been identified and related to the acceptability/partial acceptability or unacceptability of the results. The acceptability of the results has been determined in relation to the relevant characteristics of each "rich point." For example, "indiano":

- Relevant characteristics:

- a Spanish emigrant returning with a fortune from Latin America

- cohesive relation with "fortuna del americano"

- Acceptable solutions: brief explanation; omission, etc. Partially acceptable solutions: long explanation

The following tables show the data for the inverse translation distributed according to the three categories: acceptability/partial acceptability or unacceptability of the results. ${ }^{4}$

IS $=$ Simple internal support ISD $=$ Internal support dominant

IS-ES = Interaction between internal and external support

$\mathrm{ESD}=$ External support dominant

$\mathrm{T}=$ Translator

AS = Simple external support

$\mathrm{L}=$ Language teacher 


\begin{tabular}{|l|c|c|c|c|c|c|c|}
\hline $\begin{array}{l}\text { ACCEPTABLE } \\
\text { SOLUTIONS }\end{array}$ & IS & ISD & IS-ES a & IS-ES b & IS-ES c & ESD & ES \\
\hline Indiano & & T & & & & T & L \\
\hline Americano & TTTL & & & & & & \\
\hline Alfonsino & & & & & & TL & \\
\hline desenfreno y dilapidación & & & & & L & T & TL \\
\hline geografía comarcal de C. & & & & L & & & \\
\hline Comuna & & & & & & TL & \\
\hline "la trona" & TL & & T & & L & & L \\
\hline
\end{tabular}

\begin{tabular}{|l|c|c|c|c|c|c|c|}
\hline $\begin{array}{l}\text { PARTIALLY } \\
\text { ACCEPTABLE SOLUTIONS }\end{array}$ & IS & ISD & IS-ES a & IS-ES b & IS-ES c & ESD & ES \\
\hline Indiano & & & & T & & & L \\
\hline Americano & & & & & & & \\
\hline Alfonsino & & & T & & & & L \\
\hline desenfreno y dilapidación & & & & & & T & L \\
\hline geografía comarcal de C. & & & & & & & \\
\hline Comuna & & & & & & & \\
\hline "la trona" & & & & & & & \\
\hline
\end{tabular}

\begin{tabular}{|l|c|c|c|c|c|c|c|}
\hline $\begin{array}{l}\text { UNACCEPTABLE } \\
\text { SOLUTIONS }\end{array}$ & IS & ISD & IS-ES a & IS-ES b & IS-ES c & ESD & ES \\
\hline Indiano & L & & & & & & \\
\hline Americano & LL & & & & & & \\
\hline Alfonsino & T & L & & & & & \\
\hline desenfreno y dilapidación & & & & & & & \\
\hline geografía comarcal de C. & T & & & & & & TLL \\
\hline Comuna & L & T & & & & & L \\
\hline "la trona" & & & & & & & \\
\hline
\end{tabular}

\subsection{Tendencies}

The following tendencies have been observed:

1. Simple external support (ES) is used more by the language teachers than the translators. Furthermore, they are also more likely to use simple external support after internal support (IS-ES c).

2. Simple internal support (IS): (a) is used more by the language teachers to reach unacceptable solutions; (b) is used more by the translators to reach acceptable solutions. Furthermore, the translators are more likely to use predominantly internal support (ISD) and external support to confirm decisions (IS-ES a).

3. External support dominant (ESD): (a) this sequence is used more by the translators than language teachers; (b) it is the type of external support most used by the translators; (c) this sequence leads to more acceptable results (for both translators and language teachers)

4. The majority of the unacceptable solutions are provided by the language teachers and the most common sequences used to reach these unacceptable solutions are: simple internal support (IS) and simple external support (ES). 
5. The majority of the acceptable solutions (for both translators and language teachers) are reached by the use of external and internal support (ISD, IS-ES, ESD).

These first results from the pilot test seem to confirm our general hypothesis that the degree of expertise influences the translation process and product. By tracking sequences of actions we can learn more about how decision-taking functions in the translation process and the interaction between internal and external support. Furthermore, the results point to differences in the processes followed by language teachers and translators. On the other hand, the pilot test has proved the reliability of our instruments because they have allowed us to measure what we wanted to measure: the decision-taking processes followed by our two experimental groups. Hopefully, we shall soon be able to present further results.

\section{NOTES}

1. PACTE group has received support from the Spanish Ministerio de Educación y Cultura (1997-2000), the Ministerio de Ciencia y Tecnología (2001-2004) and the Generalitat de Catalunya (2002-2005).

2. This based on the distinction made by Alves $(1995,1997)$.

3. This based on the distinction made by Jakobsen (2002).

4. The translator of the text from Spanish into German did not complete the task, which explains the difference in the number of T-solutions and L-solutions.

\section{REFERENCES}

Alves, F. (1995): Zwischen Schweigen und Sprechen: Wie bildet sich eine transkulturelle Brücke? Eine Analyse von Übersetzungsvorgängen zwischen portugiesischen und brasilianischen Übersetzern, Hamburg, Dr. Kovac.

Alves, F (1997): "A formação de tradutores a partir de uma abordagem cognitiva: reflexões de um projeto de ensino," TradTerm, Revista do Centro Interdepartamental de Tradução e Terminologia, 4-2, p. 19-40.

Jakobsen, A.L. (2002): "Orientation, Segmentation, and Revision in Translation," in Hansen, G. (ed.). Empirical Translation Studies: Process and Product. Copenhagen Studies in Language Series 2,. Copenhagen, Samfundslitteratur, p. 191-204.

Neuzig, W. (2000): “The Computer in Empirical Studies for the Didactics of Translation," in A. Beeby, D. Ensinger, M. Presas, M. (eds.): Investigating Translation, Amsterdam, John Benjamins Publishing Company, p. 91-99.

PACTE (1998a): "La competencia traductora y su aprendizaje: Objetivos, hipótesis y metodología de un proyecto de investigación," IV Congrés Internacional sobre Traducció, Universitat Autònoma de Barcelona (poster).

PACTE (1998b): "Procesos de aprendizaje y evaluación en la adquisición de la competencia traductora," European Society for Translation Studies - Congress Granada 1998, Granada.

PACTE (2000): "Acquiring Translation Competence: Hypotheses and Methodological Problems in a Research Project," in A. Beeby, D. Ensinger, M. Presas (eds.) Investigating Translation, Amsterdam, John Benjamins, p. 99-106.

PACTE (2001): "La Competencia traductora y su adquisición," Quaderns. Revista de Traducció, 6, p. 39-45.

PACTE (2002): “Exploratory Tests in a Study of Translation Competence," Conference Interpretation and Translation, 4-2, p. 41-69.

PACTE (2003): "Building a Translation Competence Model," in Alves, F. (ed.) Triangulating Translation: Perspectives in Process Oriented Research, Amsterdam, John Benjamins, p. 43-66. 


\section{APPENDIXES}

APPENDIX 1: DIRECT OBSERVATION CHART

STAGE: Orientation/Development/Revision

STARTING TIME: . . .

\begin{tabular}{|l|l|l|l|l|}
\hline Time & \multicolumn{2}{|l|}{ Action } & Text segment & $\begin{array}{l}\text { Commentaries and } \\
\text { consultation details }\end{array}$ \\
\hline & Reading & Consultation & & \\
\hline & Pause & Other & & \\
\hline & Reading & Consultation & & \\
\hline & Pause & Other & & \\
\hline
\end{tabular}

\section{APPENDIX 2: PROBLEMS QUESTIONNAIRE}

1. The five most problematic elements to translate

\begin{tabular}{|l|l|}
\hline Problem 1: & $\begin{array}{l}\text { Why do you consider this to be an important problem? } \\
\text { Are you satisfied with your solution? Yes } \square \text { No } \square \text { Why? }\end{array}$ \\
\hline
\end{tabular}

2. Indicate the degree of difficulty of this translation

\begin{tabular}{|l|l|l|l|l|l|l|}
\hline 1 & 2 & 3 & 4 & 5 & 6 & 7 \\
\hline
\end{tabular}

\section{APPENDIX 3: TRANSLATION KNOWLEDGE QUESTIONNAIRE}

Give your opinion in relation to the following statements

1. When I'm reading the source text, I'm already thinking about how to translate it.

This coincides with my opinion: Not at all $\square$ a little $\square$ a lot $\square$ totally $\square$

2. Words usually have different nuances of meaning in different languages, so something is lost in all translations.

This coincides with my opinion: Not at all $\square$ a little $\square$ a lot $\square$ totally $\square$

3. The same word can be translated in different ways depending on the text.

This coincides with my opinion: Not at all $\square$ a little $\square$ a lot $\square$ totally $\square$

\section{APPENDIX 4: CHART OF CONSULTATION CATEGORIES}

\begin{tabular}{|c|c|c|}
\hline TYPE OR RESOURCE & MEDIUM & LANGUAGES IMPLIED \\
\hline 1. General dictionaries & 1. Paper & 1. Source language \\
\hline 2. Language reference works & $\begin{array}{l}\text { 2. Hard disk, diskette } \\
\text { and CD-Rom }\end{array}$ & 2. Target language \\
\hline 3. Field reference works & 3. On-line & 3. Bilingual \\
\hline $\begin{array}{l}\text { 4. Specialized dictionaries, glossaries } \\
\text { and terminological data banks }\end{array}$ & & 4. Multilingual \\
\hline 5. Parallel texts & & 5. Other language \\
\hline $\begin{array}{l}\text { 6. Searchers. Contextualized search } \\
\text { in searchers }\end{array}$ & & \\
\hline
\end{tabular}

